УДК [342.5-048.24 : $328.185: 94]$ (315)

DOI: https://doi.org/10.33782/eminak2019.3(27).321

\title{
ІМПЕРАТОРСЬКА СИСТЕМА ІСПИТІВ У СТАРОДАВНЬОМУ КИТАЇ ЯК МЕТОД ЗАПОБІГАННЯ КОРУПЦІЇ
}

\author{
Анастасія Маслова \\ Університет Фудань (Шанхай, Китай) \\ e-mail: 17210170456@fudan.edu.cn \\ ORCID: https://orcid.org/0000-0002-0014-3592
}

у статті досліджутьься давньокитайська екзаменаційна система, яка стала «n'ятим найбільшим винаходом» Китаю для формування прозорої урядової політики. Традиція складання екзаменів на державну службу в сучасних західних країнах бере свій початок від системи імператорських іспитів Стародавнього Китаю, адже Китай став першою країною у світі, яка обирає чиновників таким шляхом. Проте запобігання корупції на державній службі є найбільш серйозною та важливою проблемою серед усіх ії проявів.

Ключові слова: імператорська екзаменаційна система, урядова політика, вища справедливість, іспит, корупція

Поміж усіх видів загальних проблем сучасного суспільства хабарництво на іспитах, як вид корупції, є найбільш значним в очах широкої громадськості. Для уникнення цього та побудови сьогоденної прозорої урядової культури, особливо у питаннях зазначених вище, велике значення має сама система іспитів. Тому актуальність і необхідність дослідження давньокитайської імперської екзаменаційної системи, яка існує уже понад 1300 років, і є не лише важливим наріжним каменем феодальної політики та стародавньої культури, але й «п'ятим найбільшим винаходом» Китаю, що слугує значним внеском в історію світової цивілізації, є беззаперечними. Саме Китай став першою країною у світі, де обирають чиновників шляхом іспитів і претенденти могли продемонструвати свої знання й отримати високу державну посаду за рівень освіти та високу кваліфікацію, а не за родовими, клановими чи іншими зв'язками. Тож система іспитів грала й роль своєрідного соціального ліфта.

Більше того, сучасна західна система екзаменів на державну та громадську службу походить від давньокитайської імператорської системи іспитів. Фактично усі види сучасних систем іспитів, у тому числі на державну службу, містять культурні традиції імператорської експертизи. Тож дослідження давньокитайського винаходу системи проходження іспитів для претендентів на державні посади, як елемент боротьби з корупцією, залишається актуальним.

Методологічною основою у дослідженні став метод історизму для вивчення виникнення, формування та розвитку культу «справедливого правителя», який рішуче запобігав або карав прояви шахрайства та захищав інтереси громадян. Окрім того залучено методи аналізу та порівняння, які дозволили зрозуміти сутність давньокитайської системи імперських іспитів, як ефективної системи запобігання корупції, зокрема фаворитизму з боку екзаменаторів та обособлення випробовуваних.

Досліджуючи давньокитайську системи імперських іспитів, наголосимо, що найперший опис системи іспитів Китаю було зроблено ще у другій половині XVI ст. Гаспаром-да-Крузом і Хуном Гонсалес де Мендоком. Зокрема Гаспар-да-Круз, який від- 
плив до Китаю у 1556 р., вже у 1569 р. опублікував свої враження від подорожі1. Дослідник згадував, що відбір чиновників у Китаї відбувався шляхом перевірки знань, а також описав звання кандидатів та учених на посади. Більш докладно система імператорських іспитів Китаю і положення про неї описані в «Історії Великого і Могутнього Королівства Китаю», яка була опублікована в Лондоні у 1588 р. Хуном Гонсалес де Мендоком. Докладні описи системи іспитів присутні в «Анатомії меланхолії» Роберта Бертона².

У середині - другій половині XX ст. Коріг у статті, опублікованій в Гарвардському журналі азіатських досліджень у 1947 р., вперше зазначав, що створення офіційної адміністративної системи з імператорськими іспитами стало одним з найважливіших внесків Китаю у світову культуруз3. Пізніше Гу Лія у книзі «Походження китайської політики і мистецтва» пояснював, що після детального вивчення історії системи іспитів він виявив, що Китай став першою країною, що прийняла цю традицію.

Дослідження імператорської системи іспитів, а також аналіз видозмін і розвитку культу «вищої справедливості», має велике значення для побудови сьогоденної прозорої урядової культури. Тож розглянемо ії докладніше.

\section{1. Життєздатність системи імператорських іспитів як культ вищої справед- ливості.}

Імператорські іспити відіграють важливу роль у традиційній соціальній структурі Китаю. Це не тільки важливий засіб для уряду виокремити талановитих людей і мотивувати їх, але й єдиний спосіб для інтелектуалів реалізувати свій ідеал миру. Незважаючи на те, що система імператорських іспитів була скасована у 1905 р., і тоді ж закінчилася її історична місія, незаперечним $є$ факт того, що ця система відіграла позитивну історичну роль у політиці, культурі й освіті стародавнього Китаю. Більшість політиків минулих династій прийшли на історичну сцену саме завдяки цій традиції.

Чому ж імператорська екзаменаційна система тривала 1300 років і стала «вічною системою» для підбору професіоналів у династіях Суй, Тан, Юань, Мін і Цін? Адже суть цієї традиції полягала у тому, що вона уособлювала в собі основні принципи рівності, відкритості та відбору досконалості, і втілювала дух «вищої справедливості» ${ }^{4}$, який проявлявся у двох аспектах.

По-перше, з точки зору кваліфікаційної оцінки, екзаменаційна система дозволяла кандидатам добровільно подати заявку. Вони могли брати участь в іспитах незалежно від багатства, рівня достатку та попередньої посади (за винятком сфер промисловості і торгівлі), на відміну від пасивних рекомендацій місцевих губернаторів, за системою цензури династії Хань. Загалом, система імператорських іспитів розвивалася від династій Суй і Тан до династій Мін і Цін, набуваючи все більшого впливу.

За часів династії Цін, якщо претендент, який прагнув скласти іспит на державну посаду, походив із сім'ї з «чесним ім'ям», «чию славу не затьмарювали ані злочини,

\footnotetext{
1 候建良. 中国古代文官制度. 北京: 中国人事出版社, 2010. P. 1 [Hou J. Civil Service System in Ancient China. Zhongguo Renshi Chubanshi, Beijing, 2010. 1 p.]

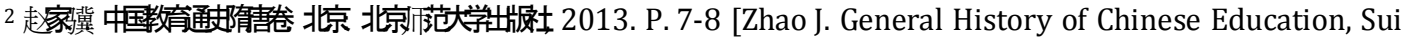
and Tang Dynasty Volumes. Beijing Shifan Daxue Chubanshe. Beijing, 2013. P. 7-8]

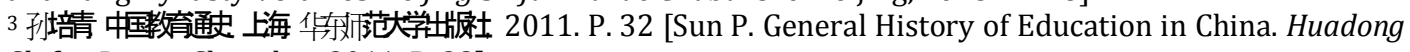
Shifan Daxue, Shanghai, 2011. P. 32]

4 张鸣. 萝卜招聘与人心世道. URL: http://blog.sina.com.cn/zhangming1 [Zhang M. Recruitment and People's Ideas (2019)]
} 
шахрайства, замовчування про похорони членів родини (це вважалося підставою для відставки у зв'язку з трауром) та інші негідні вчинки, він міг подати заяву на розгляд». Внаслідок цього імператорська система іспитів була відкрита для всіх цивільних осіб, тим самим максимально реалізуючи рівність екзаменаційних прав освічених осіб.

По-друге, з моменту появи імператорської системи іспитів вимоги ставали більш суворими й об’єктивними, що гарантувало неупередженість та авторитет системи як національної церемонії талантів. Період династії Сун став важливим етапом розвитку напрямків стандартизації та суворості у системі імператорських іспитів.

Ця система за часів династії Тан не була стандартизованою і достатньо суворою, тому реалізація «загального списку і закону про публічні рекомендацї̈ періоду правителів династії Сун Чжао Куангсу, Тайду стала великим кроком для появи «духу довіри». Вони заборонили «публічні рекомендації», які повністю відкидали інші види рекомендацій імператорської системи іспитів, гарантуючи тим самим простоту та справедливість 5 . Впровадження системи «особливих іспитів» містила:

- виключення чиновників, які мали родинні зв'язки з екзаменаторами у межах своєї провінції;

- «замикання двору» - закриття приміщень на час іспитів і таємних засідань;

- принцип заклеювання імен чиновників-учасників іспитів і копіювання робіт.

Все це зменшило кількість випадків преференцій з боку екзаменаторів, тоді як «система постійної зміни зразка екзаменаційного твору», ще більше гарантувала справедливість та об'єктивність системи екзаменів, що можна розглядати як велике нововведення. Юан Сюй одного разу сказав: «Система оновлення персоналу штату краща, ніж система попередніх поколінь»6. Така оцінка є досить доречною. Якщо у ранній період правління династії Мін було кілька спроб повторення й уподібнення до попередньої системи відбору талантів, зокрема таких як особливий та імператорський іспит, то через відсутність об'єктивних критеріїв для оцінювання, було важко покласти край корупції - призначення родичів на відповідні посади та зловживання службовим становищем.

Врешті-решт імператорський іспит був визначений як «постійна система» і став основним критерієм відбору кандидатів за часів династій Мін і Цін на найближчі 500 років.

Для забезпечення «вищої справедливості» династія Мін сформулювала надзвичайно жорсткі правила щодо процедури проведення іспитів, включаючи відбір екзаменаторів, пошук і прийом кандидатів і маркування документів учасників екзаменів. Пізніше був підданий критиці такий критерій відбору як написання есе, що початково мав за мету стандартизацію екзаменаційних робіт і сприяв отриманню об'єктивної оцінки, яка допомагала екзаменатору справедливо оцінити рівень знань. Наприклад, Лан Чжонгуй, міністр обрядів за часів династії Мін, з гордістю заявив, що «система була неупередженою більше 200 років, в залежності від імператорських іспитів» ${ }^{7}$. Причиною процвітання системи періоду її становлення був захист і підтримка принципу «максимальної неупередженості», що врешті-решт при-

\footnotetext{
5 陆游. 老学庵笔记. 上海: 上海书店, 1990, (5). P. 5 [Lu Y. Notes of Lao Xue'an, Shanghai Shudian, Shanghai, 5th ed. 1990. P. 5]

6 Ibid. P. 5-7]

7 王世贞. 弇山堂别集. 北京: 中华书局, 1985. P. 1605 [Wang S. A Special Collection of Qishan Tang, Zhong Hua Shuju, Beijing. 1985. P. 1605]
} 
звело до зниження корупції у кінці правління династії Цін. Хоча правителі оприлюднили «Положення про Імператорські Іспити» з детальними роз'ясненнями про «відбір справжніх талантів і усунення їхніх недоліків», велика привабливість іспитів мотивувала багатьох людей ризикувати та спекулювати, щоб досягти своєї мрії «про золотий список чиновницьких рангів шляхом шахрайства»8. Серед усіх видів корупційних діянь найбільш поширеним було так зване «спільництво», яке означало, що випробовувані й екзаменатори вступали у змову для отримання нечесних результатів. Наприклад, за часів династії Цін було багато випадків обману у висновках експертів, особливо в середній і пізній періоди. Попри те, що більш жорсткими вважалися імператорські іспити, навіть там мали місце прояви корупції. Феодальні правителі не могли гарантувати справедливе та чесне проведення імператорських іспитів.

Отже, причина того, що цю систему було скасовано в кінці правління династії Цін, полягала у тому, що зміст і форма іспиту, який містив есе з восьми частин, а також його стиль були застарілими та непристосованими до реалій нового часу. Проте серйозна корупція у придворному та чиновницькому середовищі ускладнювала збереження і культивування справедливості та чесності екзаменаційної системи.

\section{2. Соціальне значення імператорських іспитів для розбудови та політичної стабільності держави.}

Імператорська експертиза, яка була заснована на ідеї «вищої справедливості» при призначенні чесного та «чистого» уряду втілювалася у двох аспектах.

По-перше, система іспитів відбору кваліфікованих кадрів і принцип «винятковості таланту» були створені для того, щоб уникати та стримувати зростання корупції при призначенні представників влади. Усунути прояви аристократичних спадкових привілеїв для посадових осіб, гарантувати справедливість і прозорість офіційного працевлаштування, а також ефективно вирішувати проблему неупередженої конкурентоздатності.

По-друге, під впливом конфуціанської класичної традиції, яка забезпечувала соціальну мобільність, чиновники, які ставали представниками влади шляхом проходження імператорських іспитів, могли займати значно вищі посади, ніж завдяки аристократичній системі привілеїв. Це призвело до появи великої кількості чесних і справедливих службовців, які стали важливою силою в ефективному захисті цілісності уряду при боротьбі з корупцією в офіційних колах.

Однак, з появою нової династії Юань ця система не діяла протягом тривалого часу. Тільки четвертий їі імператор, Жень-цзун, на другий рік свого правління (1313р.) відновив систему імператорських іспитів династій Тан і Сун. «Імператор Женьцзун жив у прихованій резиденції і був втомлений від кола чиновників. Його влада була свавільною, і він сприяв розвитку бюрократії у вчених колах і при відборі на посади»9. Головною причиною для відновлення імператорської екзаменаційної системи Юань Женьцзун було вирішення питання проявів корупції посадових осіб того часу, що також ілюструвало позитивну роль цієї системи у побудові чесного уряду.

Імператори минулих династій розуміли важливість імператорських іспитів для стабілізації суспільства та заспокоєнні населення. Вони часто коригували специфічну систему іспитів відповідно до потреб загального стану країни та розвитку поточ-

8 王世贞. 畣山堂别集. 北京: 中华书局, 1985. P. 1605-1606 [Wang S. Op. cit. P. 1605-1606].

9 屈超立. 科举制的廉政效应. 北京: 政法论坛, 2001, (5). P. 155 [Qu C. The Effect of Clean Government of Imperial Examination System, Zhengfa Luntan, Beijing, $5^{\text {th }}$ ed. 2001. P. 155].

Eminak, 2019, 3 (27) 
ної ситуації, а також удосконалювали імператорські екзамени задля стабілізації політичної влади. I чим більш престижною була імператорська екзаменаційна система для громадськості, тим очевиднішою у ній відігравали імператорські іспити для соціальної та політичної стабільності. Падіння престижу «цзіньші» (вище вчене звання у системі державних іспитів) призвело до повстань наприкінці династії Тан, Хуан Чао, Ван Сіаньчжі, Лі Чжен та інших і встановлення династії Сун. «Учені, які зазнали морального падіння і лише жадають чиновницької посади, вмирають назавжди...»10.

Така ситуація спричинила низку імператорських реформ спрямованих на «умиротворення людських сердець», прийнятих правителями династії Сун. Наслідком стало те, що негативні настрої та безлад, викликаний падінням престижу імперських іспитів, був значно послаблений. Якщо династією Тан лише близько 30 чол. були допущені до імператорських іспитів, а рівень прийому становив лише 1-2\%, то починаючи з правління імператора Сун Тайцзуна (північна династія Сун) чисельність «цзіньши» збільшилася. Так середня кількість осіб, які брали участь в імператорських іспитах, досягла 186 чол., що було безпрецедентним на той час. Однак, починаючи 31057 р., династія Північної Сун провела реформу системи імператорських екзаменів, увівши систему фіксованих списків, що призвело до падіння престижу цзіньши. У ранній династії Цин правителі незабаром прийняли пропозицію Фен Веньчена відновити ускладнену процедуру імператорських іспитів задля заспокоєння народних мас ${ }^{11}$.

\section{3. Культ «справедливого правителя» як приклад запобігання корупції.}

Сьогодні гарантування справедливого оцінювання іспитів на всіх рівнях $є$ важливим аспектом чесного процесу розбудови держави та функціонування уряду. Зауважимо, що ті державні службовці, які вступають до урядових відомств через рекрутинг, родинні відносини або пошук «шпаринки» у законодавчій системі - $\epsilon$ продуктом корупції і, логічно, джерелом її поширення.

Якщо у період правління династії Хань типовою системою рекомендацій, яка сформувала ситуацію «виховання видатних талантів, ігнорування книг, підвищення релігійної побожності та чесності» 12 була цензура, то за часів династії Тан подібну роль відігравала система загальних списків як система оцінювання. Результатом цього стало запрошення та культивування королівськими сановниками і високопосадовцями «своїх людей». «У стародавньому Китаї, в країні, глибоко постраждалій від перипетій людських почуттів, відносин і культу особи, будь-який метод або система вибору талантів з елементами рекомендації неминуче призводила до зловживання владою та фаворитизму»13. Зважаючи на таку ситуацію, новий імператор Сен Тайзу суворо заборонив рекомендації. Відтоді, з поступовим вдосконаленням системи імператорських іспитів, рекомендаційна складова іспиту була повністю скасована.

Наголосимо, що імператорські іспити необов'язково були найдосконалішою системою, однак вони стали найбільш ефективним на той час методом уникнення ко-

10 屈超立. 科举制的廉政效应. 北京: 政法论坛, 2001, (5). P. 155-157 [Qu C. Op. cit. P. 155-157].

11 刘海峰. 李兵. 中国科举史. 上海: 东方出版中心, 2006. P. 228-336 [Liu H., Li B. The history of imperial examinations in China. Dongfang Chuban Zhongxin, Shanghai, 2006. P. 228-336].

12 梁晨. 李中清. 无声的革命. 中国社会科学, 2012. P. 98 [Liang C., Li Z. Silent Revolution. Zhongguo Shehui Kexue. Beijing. 2012.98 p.].

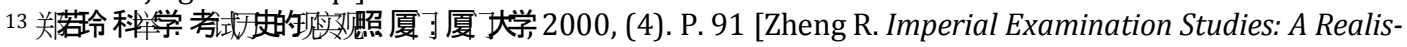
tic View of the History of Examinations. Xiamen Daxue, Xiamen, $4^{\text {th }}$ ed. 2000. P. 91]. 
рупції. «Деякі люди, здається, бачать більше недоліків у системі іспитів, забуваючи, що її скасування неминуче призведе до більших проблем, тож нам бракує кропітких зусиль, щоб знайти якусь раціональність у системі рекомендацій і виправити недоліки системи іспитів» 14.

Зважаючи на це, зауважимо, що усі види іспитів повинні повною мірою гарантувати об'єктивність і неупередженість самої системи, а також доповнюватися системою рекомендацій.

Гарантія справедливості імператорських іспитів для громадськості суттєво залежала від постійного вдосконалення законодавчої бази правителями минулих династій. Так, уведення в дію династією Сун серії законів і правил про систему іспитів, таких як: «Положення про тести передових вчених» $\mathrm{i}$ «Процедури вивчення і виправлення вчених» (1007р.), означало, що імператорська екзаменаційна система в Китаї вступила у період легалізації та стандартизації. Початкове обстеження, огляд містечка до загальної та палацової перевірки складали трирівневу систему іспитів, оприлюднену Хунву династії Мін ${ }^{15}$. Виходячи з настанов двору династії Мін, відзначимо, що регулювання процедури іспитів залежало від підбору експертів, пошуку місць проведення іспитів і маркування екзаменаційних робіт.

Таким чином імператорська екзаменаційна система династії Цін стала більш досконалою, ніж за часів попередньої династії. Саме династія Цін прийняла «Положення про Імператорську Академію», у якому вказувалося: «...точність цього положення $\epsilon$ унікальним у світі, методи запобігання шахрайства можна порівняти із герметичним посудом, вода з якого не виливається. Ті, хто не читав «Імператорські Правила», навряд чи можуть собі уявити закритість для шахрайства системи іспитів за часів династії Цін, а ті, хто читав, навряд чи можуть забути «герметичність» цієї системи»16. Маркування екзаменаційних документів, копії робіт та ін. стало ефективним механізмом запобігання корупції у розгалуженій системі іспитів.

3 метою запобігання корупції правителі давніх китайських династій прийняли значну кількість ефективних і конкретних заходів, які й сьогодні $\epsilon$ актуальними. Наприклад, за часів правління династій Тан і Сун, «особливий іспит» (для чиновників, що мають родинні зв'язки з екзаменаторами) був створений спеціально для того, щоб запобігти обману та зловживанню службовим становищем з боку екзаменаторів ${ }^{17}$. Так званий «особливий іспит» належав до категорії оцінювання, спеціально встановленої для посадових осіб (а також для дітей і родичів останніх), які знають про імператорські іспити та можуть бути їх потенційними учасниками. Через два роки Тайцзун Юнсі з династії Сун перевів цей іспит на фіксовану систему. Кожен екзаменатор провінційної екзаменаційної комісії, посадова особа префектур та округів, а також діти та родичі екзаменаторів, які могли бути учасниками іспиту, направлялися в іншу провінцію для його проходження.

Отже, методика екзаменів для призначення чиновників усіх рангів, як засіб запобігання корупції на імператорських іспитах, створена за часів правління династії Цін, знайшла своє відображення у сучасному демократичному суспільстві. Наприклад, діяла система поділу офіційної та цивільної документації. Так кількість і частка другого

\footnotetext{
14 关若令科学考式力史的现双照厦司厦大学2000, (4). P. 94 [Zheng R. Op. cit. P. 94].

15 Ibid. P. 99-100.

16 Ibid. P. 101.

17 雷颐 伟大的扶择 恢复高考. 江淮文史, 2007, (10). P. 176 [Lei Y. Great Choice: Resuming College Entrance Examination. Jianghuai Wenshi, 2007. 10 th ed. P. 176].
} 
покоління учасників екзаменів була набагато вища, ніж першого покоління вчених. Сама ж система розподілу посадових і громадських документів для сільських іспитів була оприлюднена та впроваджена на тридцять дев'ятий рік епохи династії Кансі та передбачала відбір частки студентських робіт для перевірки сільськими екзаменаторами. Вона відображала «співчуття до бідних» імператорської й урядової гілок влади задля стримування корупції в офіційних колах, а також забезпечувала принцип справедливої конкурентоспроможності серед науковців різних соціальних прошарків.

Одним із методів боротьби з фаворитизмом в академічному середовищі стало те, що династія Цін запровадила сувору систему проведення відкритих нарад для запобігання підкупу сільських екзаменаторів. Положення Імперського міністерства обрядів передбачало, що: «Синів і дочок посадових осіб, які проживають разом з батьками або не входять до прошарку тих, що розкидані в різних провінціях і мають різне походження, проживають на різних територіях, належать до різних родин, які знаходяться далеко один від одного, а також перебувають у родинних відносинах (дідусі, зяті, племінники дружин і сестер тощо) мають зазнавати ретельнішої перевірки»18.

Крім того, з огляду на випадки шахрайства при оцінюванні, особлива увага приділялася місцю проведення іспитів. Тому була сформована повна система сільського екзаменування та повторного оцінювання, яка фактично стримувала корупцію, зокрема, фаворитизму з боку екзаменаторів та обособлення випробовуваних. Таким чином, це стало спеціальним вектором системи іспитів нарівні з системою заклеювання імен за часів династії Тан і Сун. В епоху Цін ідея та культ «справедливого правителя», який рішуче запобігає або карає вияви шахрайства, рішуче захищає інтереси громадян і зберігає неупереджену систему імператорських іспитів, в очах громадськості, безсумнівно, є прикладом запобігання корупції.

Отже, у певному сенсі, неупередженість при проведенні іспитів $є$ барометром соціальної справедливості. Вей Юньчжень, імператорський ревізор династії Мін, наголошував: «Імператорська система іспитів $€$ виявом справедливості у Піднебесній...»19.

Таким чином, у суспільстві, яке має значні відмінності між багатими і бідними, між міськими та сільськими жителями, а також вразливих груп, що не має чіткої соціальної позиції та ресурсів, іспити - єдиний шанс і надія змінити своє життя на краще. Тож вивчення досвіду давньокитайської імператорської системи іспитів, зміцнення правового нагляду, рішуче покарання корупції може стати важливою частиною прозорої урядової політики сучасних демократичних країн.

\section{REFERENCES}

Hou, J. (2010). Civil Service System in Ancient China. Zhongguo Renshi Chubanshi, Beijing [in China].

Lei, Y. (2007). Great Choice: Resuming College Entrance Examination. Jianghuai Wenshi [in China].

Liang, C., \& Li, Z. (2012). Silent Revolution. Zhongguo Shehui Kexue, Beijing [in China].

Liu, H., \& Li, B. (2006). The history of imperial examinations in China. Dongfang Chuban Zhongxin, Shanghai, 228-354 [in China].

Lu, Y. (1990). Notes of Lao Xue'an. Shanghai Shudian, Shanghai, 5-7 [in China].

Qu, C. (2001). The Effect of Clean Government of Imperial Examination System. Zhengfa Luntan, Beijing, 155-157 [in China].

Sun, P. (2011). General History of Education in China. Huadong Shifan Daxue, Shanghai [in China].

Wang, S. (1985). A Special Collection of Qishan Tang. Zhong Hua Shuju, Beijing, 1604-1605 [in China].

Zhang, M. (n.d.). Recruitment and People's Ideas. Retrieved from: http://blog.sina.com.cn/zhangming1

18 张萱. 西园闻见录: 礼部.选举科场. 南京: 哈佛燕京学社. 1940. P. 11 [Zhang X. Hearing and Recording of Xiyuan: Ministry of Rites. Hafo Yanjing Xueshe. 1940. P. 11].

19 Ibid. P. 16. 
(accessed 5 June 2019) [in China].

Zhang, X. (1940). Hearing and Recording of Xiyuan: Ministry of Rites. Hafo Yanjing Xueshe, 11-18 [in China].

Zhao, J. (2013). General History of Chinese Education, Sui and Tang Dynasty Volumes. Beijing Shifan Daxue Chubanshe, Beijing, 7-15 [in China].

Zheng, R. (2000). Imperial Examination Studies: A Realistic View of the History of Examinations. Xiamen Daxue, Xiamen, 91-101 [in China].

\section{Anastasiia Maslova}

(Fudan University, School of International Relations and Public Affairs, Shanghai, China)

ORCID: https://orcid.org/0000-0002-0014-3592

\section{The Imperial Examination System in Ancient China as a Method of Preventing Corruption}

Corruption in examinations is one of the major threats in the opinion of a modern democratic society, and its prevention in civil service is the most serious and important problem among all its variations. To avoid corruption and to build a transparent government culture, the examination system is of great importance. Therefore, the studied ancient Chinese imperial examination system is not only an important cornerstone of politics and culture but also China's «fifth greatest invention», making a significant contribution to the history of world civilization. China became the first country in the world to appoint officials through examinations. It was there that applicants could demonstrate their knowledge and gain high state positions for their educational attainment and high qualification, rather than for the patrimonial, clan or other ties. Therefore, the examination system played the role of a kind of social elevator as well.

Moreover, modern Western government and civil examinations are derived from the ancient Chinese imperial examination system and contain cultural traditions of imperial expert examinations. Thus, the study of the ancient Chinese invention of passing examinations for applicants to take state positions as an element of the fight against corruption remains relevant.

The main methodological principle is the method of historicism for the study of the emergence, formation and development of the cult of the «fair ruler», which strongly prevented or punished the cases of fraud and defended the interests of citizens. The principles of analysis and comparison are also used and make it possible to explore the ancient Chinese system of imperial examinations, to understand the essence of creating an effective system of preventing corruption, in particular, the favoritism of examiners and segregation of applicants.

Therefore, impartiality in examinations is the indicator of social justice. In a society, that has significant differences between rich and poor, urban and rural residents, as well as vulnerable social groups with a lack of clear social position and resources, the examinations are the only chance and hope to change their lives for the better. That is why studying the experience of the ancient Chinese imperial examination system, strengthening of legal control, and resolute punishment for corruption can become an important part of the transparent government policy of modern democratic countries.

Keywords: imperial examination system, state policy, higher justice, examination, corruption 